\title{
Shiitake Mycelial Leachate Suppresses Growth of Some Bacterial Species and Symptoms of Bacterial Wilt of Tomato and Lima Bean in vitro
}

\author{
R. P. Pacumbaba, Professor of Plant Pathology; Caula A. Beyl, Professor of Stress Physiology; and R. O. \\ Pacumbaba, Jr., Ph.D. candidate of Stress Physiology, Department of Plant, Soil, and Animal Sciences, Alabama \\ A \& M University, Normal 35762
}

\begin{abstract}
Pacumbaba, R. P., Beyl, C. A., and Pacumbaba, R. O., Jr. 1999. Shiitake mycelial leachate suppresses growth of some bacterial species and symptoms of bacterial wilt of tomato and lima bean in vitro. Plant Dis. 83:20-23.

Mycelial leachate of shiitake mushroom inhibited growth of Pseudomonas syringae pv. glycinea, $P$. syringae pv. tabaci, Xanthomonas campestris pv. glycines, X. campestris pv. campestris, Erwinia amylovora, Ralstonia solanacearum, Curtobacterium flaccumfaciens pv. flaccumfaciens, Bacillus cereus, Escherichia coli, Listeria monocytogenes, Salmonella typhimurium, and Staphylococcus aureus. The mycelial leachate applied as soil drench prevented symptom expression of bacterial wilt of tomato and lima bean in the laboratory. The results suggested that the shiitake mycelia leachate contained an antibiotic ingredient.
\end{abstract}

Additional keywords: Lentinula edodes, mycelial leachate, shiitake mushroom, wilt

Widespread use of pesticides for pest and disease control is of great concern to the public because of its effect on groundwater and air pollution and the risk to both human health and the ecosystem. Nonchemical (biological) control of plant pathogens has received much attention worldwide.

Cortinellin, a compound isolated from shiitake mushroom (Lentinula edodes (Berk) Pegler) showed antibiotic activity against Candida albicans, Staphylococcus aureus, and Bacillus subtilis (1). Also, extracts from basidiocarps and mycelia of shiitake mushroom have been reported to have important medicinal properties (2,5,14-19). Dry rot of potato caused by Gibberella pulicaris has been controlled by strains of Pseudomonas, Enterobacter, and Pantoea (13) and root disease of cucumber caused by Pythium aphanidermatum has been reduced in the soil by the presence of Pseudomonas corrugata and $P$. fluorescence (11). There has been no report of the

Corresponding author: R. P. Pacumbaba

E-mail: aamrpp01@aamu.edu

Contribution of Alabama A \& M University Agricultural Experiment Station as Journal article 386. Research was supported by CSREES/USDA 95113 Shiitake Research, Project Number ALAX011-494.

Accepted for publication 18 September 1998.

Publication no. D-1998-1109-01R

(C) 1999 The American Phytopathological Society mycelial leachate of a fungus, in this case $L$. edodes, which inhibits the growth of soilborne plant pathogenic bacteria.

The objective of this study was to determine the activity of the mycelial leachate of $L$. edodes on the growth of several important species of bacteria which are either plant pathogenic or cause disease in humans.

\section{MATERIALS AND METHODS}

Bacterial source. Plant-pathogenic bacteria used in this study were isolated from infected plant materials and purified by single colony growth on nutrient agar. Pure cultures of Pseudomonas syringae pv. glycinea (causal agent of bacterial blight of soybean), $P$. syringae pv. tabaci (causal agent of wildfire of soybean), Erwinia amylovora (causal agent of fire blight of apple and pear), and Xanthomonas campestris pv. glycines (causal agent of bacterial pustule of soybean) were obtained. Bacteria obtained from soybean were inoculated back to healthy soybean leaves for pathogen identification. Soybean leaves were placed inside high-humidity sterile glass mini-chamber Petri dishes ( 150 by 25 $\mathrm{mm}$ ) with filter paper inside (Whatman \#1 circle, $150 \mathrm{~mm}$ in diameter). The filter paper was moistened with sterile distilled water and soybean leaves were placed on it. Each soybean leaf was sprayed with a 24- to 48-h culture of a bacterial isolate in nutrient broth and incubated at room temperature $\left(21.1\right.$ to $\left.23.8^{\circ} \mathrm{C}\right)$. The control leaves were sprayed with sterile distilled water. Following the procedure above, pear leaves was also used and inoculated with pure isolate of E. amylovora. The inoculated soybean and pear leaves showed the specific symptoms of the pathogen inoculated in 4 to 7 days. $X$. campestris pv. campestris (causing black rot of crucifers) was not reinoculated to cabbage, because this pathogen was used in the dissertation of $\mathrm{P}$. Gay (Auburn University, AL). Bacterial isolates of $P$. solanacearum (Ralstonia solanacearum; batch 93-09 \#11696), causing bacterial wilt of tomato; Curtobacterium flaccumfaciens pv. flaccumfaciens (batch 12-12-84, \#23827), causing bacterial wilt of soybean and beans; and $E$. amylovora (batch 4-20-77, \#19382), causing firelight of apple and pear, were purchased from the American Type Culture Collection (ATCC; Rockville, MD). Bacteria that affect food, humans, or both, including Bacillus cereus (causing food poisoning; vomiting, diarrhea, gastroenteritis), Escherichia coli (causing gastroenteritis), Listeria monocytogenes (causing meningitis and abortion), Salmonella typhimurium (causing gastroenteritis), and Staphylococcus aureus (causing food poisoning; vomiting and loss of fluid) were supplied by A. Bhunia (Food Science, Alabama A \& M University, Normal). All isolates listed above were maintained in sterile plated nutrient agar in the laboratory.

Host plants. The inhibitory effect of shiitake mycelial leachate on $R$. solanacearum ( $P$. solanacearum) and $C$. flaccumfaciens pv. flaccumfaciens in the presence of its host plants, tomato (Lycopersicon esculentum Mill) cv. Big Boy and lima bean (Phaseolus lunatus L.) bigseeded cultivar, respectively, were determined in the laboratory. Lima bean seeds were obtained from a local grocery store and tomato seedlings were purchased from a local plant nursery.

Production of mycelial leachate. Hardwood sawdust used in this study was a combination of oak (red and white), maple, hickory, sycamore, cherry, ash, birch, and others from the sawdust of hardwood lumbers obtained from Moss Lumber Industries (Gurley, AL). The hardwood sawdust was either fresh or aged (2 to 6 months) and passed through a sieve $(\mathrm{H} 0.40 \times 1.91$ $\mathrm{cm}$, slotted; Seedburo Equipment Co., Chicago) to obtain a uniform texture be- 
fore placing it in $\mathrm{P} 4928$ culture containers $(8.89 \mathrm{~cm}$ bottom diameter by $10.80 \mathrm{~cm}$ height by $11.43 \mathrm{~cm}$ top diameter, with lid; Phytacon vessels, Sigma Chemical Co., St. Louis). To each of the P4928 culture vessels filled with hardwood sawdust, $100 \mathrm{ml}$ of YVMBS broth (0.6 g yeast extract, 60 $\mathrm{ml}$ of $\mathrm{V}-8$ vegetable juice, $52 \mathrm{~g}$ of multigrain oatmeal ground to floury texture, 10 $\mathrm{g}$ of brown sugar [semi-pure sugar condiment], and 1,000 $\mathrm{ml}$ of distilled water; 10) was added and autoclaved at 15 psi for 20 min. The cooled autoclaved vessels then were inoculated with axenic portions of agar block ( 5 by 5 by $5 \mathrm{~mm}$ ) containing shiitake mycelia which had been growing on YVMBSA medium (YVMBS broth + $10 \mathrm{~g}$ of agar; 10) and were allowed to develop abundant mycelia for 35 to 45 days. After 45 days, the hardwood sawdust overgrown with the mycelia of $L$. edodes inside the tissue culture vessel was separated from the inside wall of the container by applying finger pressure to each vessel before adding 50 to $75 \mathrm{ml}$ of sterile distilled water. The mycelia of L. edodes were soaked for 1 week at room temperature ( 21.1 to $23.8^{\circ} \mathrm{C}$ ) before the water containing the mycelial leachate was decanted into a beaker. The mycelial leachate solution was poured into a 300-ml Labconco container and frozen for 24 to $48 \mathrm{~h}$ at $-4^{\circ} \mathrm{C}$. The frozen mycelial leachate solution was freeze-dried in a Lyph-Lock 6 Liter Freeze-Dry System Model 77530 (Labconco Corp., Kansas City, MO) and the residue resuspended in $30 \mathrm{ml}$ of $0.01 \mathrm{M}$ TRIZMA at $\mathrm{pH}$ 7.0, 0.001 M EDTA buffer, resulting in a mycelia leachate solution of $10 \times$ concentration from the original volume. The concentrated mycelial leachate solution was filtered through a $3-\mu \mathrm{m}$ Whatman \#6 filter paper, then through a $0.8-\mu \mathrm{m}$ sterilization filter unit, and stored in the refrigerator at $4^{\circ} \mathrm{C}$ for future use. The soaking and collection of mycelial leachate from each container was done 3 to 4 times consecutively, resulting in recovery of more than 10 liters of the L. edodes mycelial leachate from the 150 tissue culture vessels. For the control, hardwood sawdust leachate was obtained. The procedure for obtaining hardwood sawdust leachate was the same as above except the hardwood sawdust was not inoculated with the mycelial growth of $L$. edodes.

Effect of mycelial leachate on bacteria. The effect of the mycelial leachate of L. edodes on the bacterial strains was tested in Petri dishes containing hard agar. The soft agar (liquefied) containing the bacteria to obtain a bacterial lawn was poured over the hard agar. Hard agar consisted of $\mathrm{NaCl}(5 \mathrm{~g})$, tryptone (10 g), agar $(15 \mathrm{~g})$, thymine $(10 \mathrm{mg})$, and distilled water $(1,000 \mathrm{ml})$. Soft agar consisted of $\mathrm{NaCl}$ $(0.5 \mathrm{~g})$, tryptone $(1 \mathrm{~g})$, agar $(0.7 \mathrm{~g})$, thymine $(1 \mathrm{mg})$, and distilled water (100 $\mathrm{ml})$. Hard agar in a 1,000-ml Erlenmeyer flask and soft agar in a 100-ml milk bottle were autoclaved at 15 psi for $20 \mathrm{~min}$. When the hard agar cooled to $50^{\circ} \mathrm{C}, 10$ to $15 \mathrm{ml}$ was poured into each sterile disposable Petri dish (100 by $15 \mathrm{~mm}$ ) and kept at room temperature until use. Prior to assay, the soft agar was liquefied and maintained at $48^{\circ} \mathrm{C}$ in a water bath together with a basket containing sterile test tubes. Liquefied soft agar $(2 \mathrm{ml})$ was pipetted to each test tube along with $0.2 \mathrm{ml}$ of exponentially growing bacteria (24- to 48-h cultures) in nutrient broth. The soft agar-bacteria mixture was vortexed and poured immediately over the hard agar to obtain a bacterial lawn. Care was taken to ensure that the surface of the hard agar was completely covered with the soft agar-bacteria mixture. When the soft agar-bacteria had hardened, a drop $(20 \mu \mathrm{l})$ of the $10 \times$ concentrated mycelial leachate solution was placed on the center surface of the bacterial lawn in a Petri dish and incubated at $32^{\circ} \mathrm{C}$ for 24 to $48 \mathrm{~h}$. Two sets of controls were used. One received $20 \mu \mathrm{l}$ of buffer and another received $20 \mu \mathrm{l}$ of hardwood sawdust leachate. The diameter of the zone with no bacterial growth was measured, with an indication of whether the zone was clear or cloudy. The experimental design was a randomized block with three replications. Data was analyzed statistically according to Tukey's studentized range (HSD) test and analysis of variance (ANOVA).

Effect of mycelial leachate on bacteria and hosts. Tissue culture vessels (P4928) were filled with vermiculite and pro-mix (1:1; Premier Horticulture Inc., Red Hill, PA) and autoclaved at 15 psi for $20 \mathrm{~min}$. The cooled vessels containing the substrates were treated as follows: (A) One tissue culture vessel was inoculated by pouring or drenching $50 \mathrm{ml}$ of a 24 - to 48 $\mathrm{h}$ culture of $R$. solanacearum $\left(5 \times 10^{8}\right.$ bacterial cells per $\mathrm{ml}$ determined through serial dilution plating method) in nutrient broth. (B) Another tissue culture vessel was inoculated the same as treatment $A$ and drenched with $50 \mathrm{ml}$ of $10 \times$ concentrated mycelial leachate of $L$. edodes. (C) Two sets of control vessels were used. One was inoculated by drenching $50 \mathrm{ml}$ of hardwood sawdust leachate and another by using $50 \mathrm{ml}$ of sterile distilled water. On the fourth day after the bacterial inoculation, the culture vessels, including the controls, were planted with 3- to 4-week-old 'Big Boy' tomato seedlings. The experiment was repeated three times.

In another experiment, the same number of culture vessels were filled with vermiculite and pro-mix (1:1) and autoclaved at $15 \mathrm{psi}$ for $20 \mathrm{~min}$. The cooled vessels containing the substrates were treated as follows: (A) One tissue culture vessel was inoculated by pouring or drenching $50 \mathrm{ml}$ of a 24- to 48-h culture of C. flaccumfaciens pv. flaccumfaciens $(4 \times 108$ bacterial cells per ml) in nutrient broth. (B) Another tissue culture vessel was inoculated the same as treatment A and drenched with 50 $\mathrm{ml}$ of $10 \times$ concentrated mycelial leachate of L. edodes. (C) Two sets of control vessels were used. One was inoculated by pouring or drenching $50 \mathrm{ml}$ of hardwood sawdust leachate and another by using sterile distilled water. The treated culture vessels, including the controls, were immediately planted with lima bean seed (3 seeds/vessel). When the seeds germinated in 5 to 7 days, they was thinned to 1 seed-

Table 1. The effect of the mycelial leachate of Lentinula edodes on the growth of the bacterial isolates in the laboratory ${ }^{x}$

\begin{tabular}{|c|c|}
\hline Bacterial pathogens assayed & Zone of no bacterial growth $(\mathrm{mm})^{y}$ \\
\hline \multicolumn{2}{|l|}{ Phytopathogenic bacteria } \\
\hline Pseudomonas syringae pv. glycinea (local) & $14 \mathrm{~b}$ \\
\hline P. syringae pv. tabaci (local) & $16 \mathrm{ab}$ \\
\hline Xanthomonas campestris pv. glycines (local) & $14 \mathrm{~b}$ \\
\hline X. campestris pv. campestris (from P. Gay) & $17 \mathrm{a}$ \\
\hline Erwinia amylovora (local) & $16 \mathrm{ab}$ \\
\hline E. amylovora $(\mathrm{ATCC})^{\mathrm{z}}$ & $16 \mathrm{ab}$ \\
\hline Ralstonia solanacearum (ATCC) & 17 a \\
\hline Curtobacterium flaccumfaciens pv. flaccumfaciens (ATCC) & $14 \mathrm{~b}$ \\
\hline Control (hardwood sawdust leachate) & $0 \mathrm{c}$ \\
\hline Control (buffer) & $0 \mathrm{c}$ \\
\hline \multicolumn{2}{|l|}{ Bacteria that infect food and humans } \\
\hline Bacillus cereus & $25 \mathrm{~b}$ \\
\hline Escherichia coli & $20 \mathrm{c}$ \\
\hline Listeria monocytogenes & $25 \mathrm{~b}$ \\
\hline Staphylococcus aureus & $30 \mathrm{a}$ \\
\hline Salmonella typhimurium & $20 \mathrm{c}$ \\
\hline Control (hardwood sawdust leachate) & $0 \mathrm{~d}$ \\
\hline Control (buffer) & $0 \mathrm{~d}$ \\
\hline \multicolumn{2}{|c|}{$\begin{array}{l}\text { x Mycelial leachate solution of } L \text {. edodes was a } 10 \times \text { concentrate of the original leachate obtained } \\
\text { from } 50 \mathrm{ml} \mathrm{H} \mathrm{H}_{2} \mathrm{O} / \mathrm{vessel} / \text { week of soaking, concentrated by lyophilization, and resuspended in } 0.01 \\
\text { M TRIZMA- } 0.001 \mathrm{M} \text { EDTA buffer. A drop }(20 \mu \mathrm{l}) \text { of the hardwood leachate (also } 10 \times \text { concentrate) } \\
\text { and buffer were used as controls. } \\
\text { yest at } P=0.05 \text {. } \\
\text { te } \mathrm{ATCC}=\text { American Type Culture Collection. }\end{array}$} \\
\hline
\end{tabular}


ling/vessel. The experiment was repeated three times.

In both experiments, the inoculated and control plants were incubated at room temperature $\left(21.1\right.$ to $\left.23.8^{\circ} \mathrm{C}\right)$. The disease severity score for both bacterial wilts was on a scale of 0 to 5 ; where $0=$ healthy with no symptoms of wilting and $5=$ plant permanently wilted and dying.

\section{RESULTS AND DISCUSSION}

This is the first time that mycelial leachate of $L$. edodes has been reported to inhibit the growth of several species of bacteria affecting humans and plants. The mycelial leachate-bacteria assay resulted in significant $(P=0.05)$ growth inhibition with clear zones of growth inhibition of all species of plant-pathogenic bacteria tested in the laboratory (i.e., $P$. syringae pv. glycinea, $P$. syringae pv. tabaci, $X$. campestris pv. glycines, Erwinia amylovora, X. campestris pv. campestris, $R$. solanacearum, and C. flaccumfaciens pv. flaccumfaciens; Table 1). The mycelial leachate also significantly $(P=0.05)$ inhibited the growth of bacteria affecting food and humans: $B$. cereus, Escherichia coli, Listeria monocytogenes, Salmonella typhimurium, and Staphylococcus aureus (Table 1). The observed zone of inhibition was similar in all cases. Preliminary studies reported earlier had similar results (9). Bianco (1) also reported that Cortinellin, a compound isolated from shiitake mushroom, had antibiotic activity against Candida albicans, $S$. aureus, and B. subtilis. The inhibition zone caused by the mycelial leachate of the bacterial species tested ranged in size from 14 to $17 \mathrm{~mm}$ in diameter for pathogenic bacteria and from 20 to $30 \mathrm{~mm}$ in diameter for bacteria affecting food and humans.

The tomato seedling cv. Big Boy, grown in vessels containing sterile vermiculite:pro-mix (1:1) combinations and inoculated with $R$. solanacearum alone, showed wilting of seedlings (disease severity score of 3 on a scale of 0 to 5 ) within 17 to 22 days after inoculation (Fig. $1 \mathrm{~A}$ and $\mathrm{B}$ ). Lima bean seedlings, growing in similar vessels inoculated with $C$. flaccumfaciens pv. flaccumfaciens alone, also showed wilting of seedlings (disease severity score of 3 on a scale of 0 to 5) within 21 to 22 days after inoculation (Fig. $2 \mathrm{~A}$ and $\mathrm{B})$. The roots of wilted seedlings of tomato and lima bean appeared unhealthy and poorly developed (Figs. 1B and 2B). Neither tomato or lima bean seedlings grown in vessels containing sterile vermiculite:pro-mix $(1: 1)$ combinations inoculated with $R$. solanacearum or $C$. flaccumfaciens pv. flaccumfaciens and soil drenched with the mycelial leachate, or the control seedlings, showed any wilt symptoms even 40 days after transplantation or germination, respectively (Figs. $1 \mathrm{~A}$ and $2 \mathrm{~A})$. The present results suggest the possibility for control of soilborne bacterial
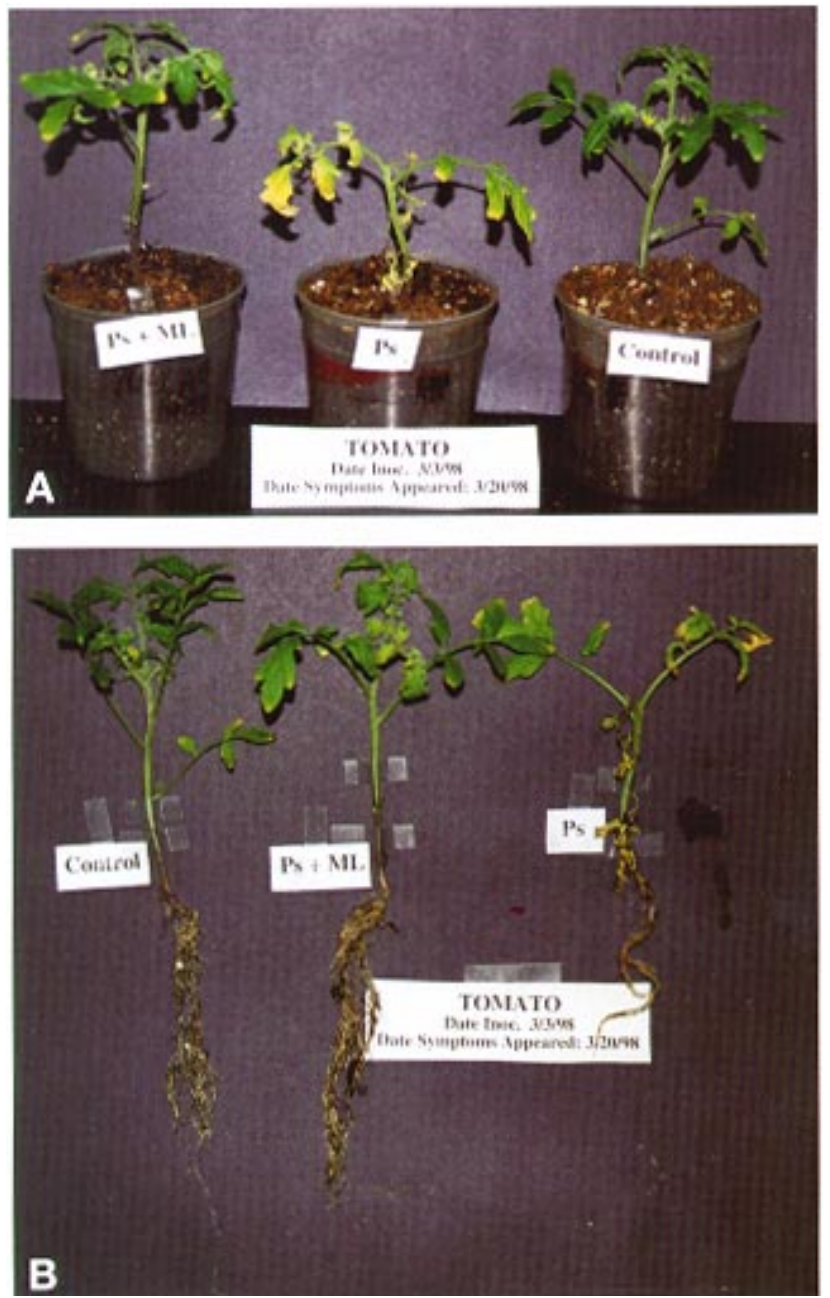

Fig. 1. (A) Tomato seedlings from Ralstonia solanacearum-inoculated vessel (center) showed symptoms of bacterial wilt (disease severity score of 3 on a scale of 0 to 5) 17 days after transplanting, while seedlings from $R$. solanacearum + mycelial leachate-inoculated and the control vessels did not show symptoms of wilting. (B) Seedlings inoculated with $R$. solanacearum alone had fewer roots. Ps $=R$. solanacearum (Pseudomonas solanacearum) and $\mathrm{ML}=$ mycelia leachate.
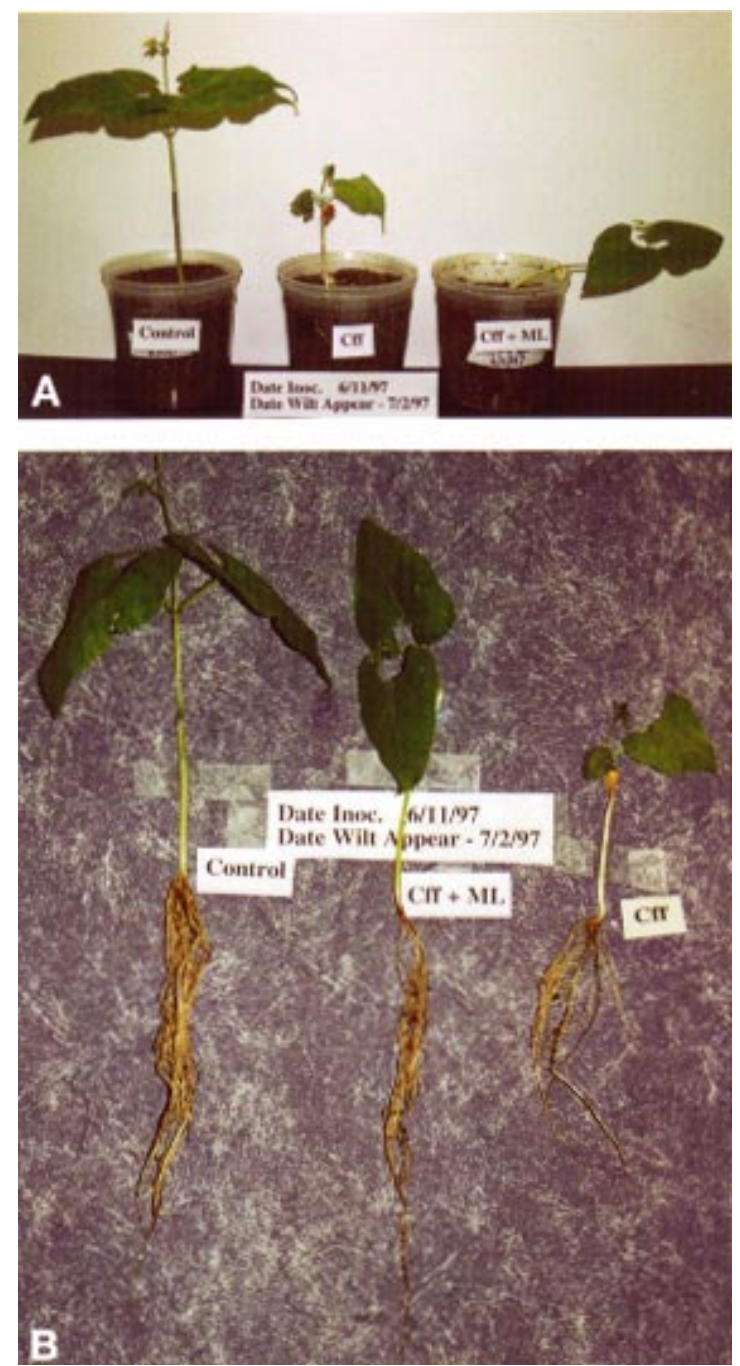

Fig. 2. (A) Lima bean seedling from Curtobacterium flaccumfaciens pv. flaccumfaciens-inoculated vessel (center) showed symptoms of bacterial wilt (severity score of 3 on a scale of 0 to 5) 21 days after germination, while seedlings from $C$. flaccumfaciens pv. flaccumfaciens + mycelial leachateinoculated and the control vessels did not show symptoms of wilting. (B) Seedling inoculated with $C$. flaccumfaciens pv. flaccumfaciens alone had fewer roots. $\mathrm{Cff}=C$. flaccumfaciens pv. flaccumfaciens and $\mathrm{ML}=$ mycelia leachate. 
pathogens using mycelial leachate applied as soil drench. The results also indicate that the shiitake mycelial leachate contains an antibiotic component. The makeup and description of the antibiotic constituent of the mycelial leachate was not investigated in this study. No study on the inhibitory effect of the mycelial leachate of Lentinula edodes on the growth of phytopathogenic fungi was performed. There have been previous reports of fungi $(3,6,12,20,21)$ and bacteria $(4,7,8)$ as biological control agents against plant-pathogenic fungi. No mycelial leachate of a beneficial fungus has been reported that inhibits growth of soilborne bacterial plant pathogens in vitro.

\section{ACKNOWLEDGMENTS}

We thank G. C. Sharma, Chairman of the Department, for his encouragement to do research on the shiitake mushroom; and the staff for their invaluable help.

\section{LITERATURE CITED}

1. Bianco, C. 1981. Basidiomycetes in relation to antibiosis. II. Antibiotic activity of mycelia and culture liquids. Bact. Viral Immunol. (Italy) 75:627-274

2. Breene, W. M. 1989. Nutritional and medicinal value of exotic mushrooms. Pages 87-112 in: Proc. Nat. Symp. Trade Show. St. Paul, MN.

3. Cotty, P. J. 1994. Influence of field application of an atoxigenic strain of Aspergillus flavus on the population of A. flavus infecting cotton bolls and on the aflatoxin content of cottonseeds. Phytopathology 84:1270-1277.

4. Goodman, D. M., and Burpee, L. L. 1991. Biocontrol of dollar spot disease of creeping bentgrass. Phytopathology 81:1438-1446.
5. Hokama, Y., and Hokama, J. L. R. Y. 1981. In vitro inhibition of platelet aggregation with low dalton compounds from aqueous dialysate of edible fungi. Res. Commum. Chem. Pathol. Pharmacol. 31:177-180.

6. Howell, C. R., and Stipanovic, R. D. 1995. Mechanism in the biocontrol of Rhizoctonia solani-induced cotton seedling disease by Gliocladium virens: Antibiosis. Phytopathology 85:469-472.

7. Leeman, M., Pelt, J. A., van., Hendricks, M. J., Scheffer, R. J., Bakker, H. M., and Schippers, B. 1995. Biocontrol of Fusarium wilt of radish in commercial greenhouse trials by seed treatment with Pseudomonas fluorescencs WCS374. Phytopathology 85:13011305.

8. Nelson, E. B., and Craft, C. M. 1991. Introduction and establishment of strains of Enterobacter cloacae in golf course turf for the biological control of dollar spot. Plant Dis. 75:410-514.

9. Pacumbaba, R. P. 1997. Mycelial leachate of shiitake mushroom inhibit growth of bacterial pathogens in laboratory. (Abstr.) Phytopathology 87:S73.

10. Pacumbaba, R. P., and Pacumbaba, R. O., Jr. Shiitake mushroom growth on the formulated culture media, production of spawn, and basidiocarps in the laboratory. HortTechnology. In press.

11. Ranking, L., and Paulitz, T. C. 1994. Evaluation of rhizosphere bacteria for biological control of Pythium root rot of greenhouse cucumbers in hydroponic culture. Plant Dis. 78:447-451.

12. Restanio, J. B., Lewis, J. A., and Lumsden, R. D. 1994. Influence of isolate of Gliocladium virens and delivery system on biological control of southern blight on carrots and tomato in the field. Plant Dis. 78:153-156.

13. Schisler, D. A., and Slininger, P. J. 1994.
Selection and performance of bacterial strains for biologically controlling Fusarium dry rot of potatoes incited by Gibberella pulicaris. Plant Dis. 78:251-255.

14. Sugano, N., Hibino, Y., Choji, Y., and Maeda, H. 1982. Anticarcinogenic actions of watersoluble and alcohol-soluble fractions from culture medium of Lentinus edodes mycelia. Cancer Lett. 17:109-114.

15. Suzuki, F., Suzuki, C., Shimomura, E. Maeda, H., Fuji, T., and Ishida, N. 1979. Antivira and interferon-inducing activities of a new peptidomannan, KS-1, extracted from culture mycelia of Lentinus edodes. J. Antibiot. (Tokyo) 32:1336-1345.

16. Takazawa, H., Tajima, F., and Miyashita, C. 1982. An antifungal compound from shiitake (Lentinus edodes). J. Pharmacol. Soc. Jpn. 102:489-491.

17. Takehera, M., Mori, K., Kuida, K., and Hanawa, M. A. 1981. Antitumor effect of viruslike particles from Lentinus edodes (shiitake) on Ehrlich ascites carcinoma in mice. Arch. Virol. 68:297-301.

18. Tokita, F., Shibukawa, N., Yasumoto, T., and Kaneda, T. 1972. Isolation and chemical structure of the plasma-cholesterol reducing substances from shiitake mushroom. Mushroom Sci. 8:783-788.

19. Tsunoda, A., and Ishida, N. 1969. A mushroom extract as an interferon inducer. Ann. N. Y. Acad. Sci. 173:719-726.

20. Wilhite, S. E., Lumsden, R. D., and Straney, D. C. 1994. Mutational analysis of gliotoxin production by the biocontrol fungus Gliocladium virens in relation suppression of $\mathrm{Py}$ thium damping-off. Phytopathology 84:816821.

21. Yuen, G. Y., Craig, M. L., and Giesler, L. J. 1994. Biological control of Rhizoctonia solani on tall fescue using fungal antagonists Plant Dis. 78:118-123. 